\title{
Response of adult male rats to LH-RH after neonatal immunization with antiserum to LH-RH
}

\author{
B. B. Bercu† and I. M. D. Jackson*
}

*Division of Endocrinology, Department of Medicine, New England Medical Center Hospital, Tufts University School of Medicine, Boston, Massachusetts 02111, and Division of Pediatric Endocrinology, Department of Pediatrics, Massachusetts General Hospital, Harvard Medical School, and Neonatal and Pediatric Medicine, NICHD, NIH, Bethesda, Maryland 20205, U.S.A.

Summary. Male rats were passively immunized at Day 5 of age with LH-RH antiserum. Their response to LH-RH at 100 days of age was examined. Serum FSH and LH concentrations increased more than in control rats, although basal plasma levels were similar. The pituitary content of $\mathbf{L H}$, but not FSH, was significantly increased, and hypothalamic content of LH-RH was similar in both groups. The testes and seminal vesicles were smaller in experimental animals than in controls. It is suggested that transient blockade of LH-RH secretion during the neonatal period produces abnormalities in pituitary-testicular function in the adult rat.

\section{Introduction}

Studies with pharmacological doses of exogenous testosterone early in neonatal life have demonstrated a 'critical period' in the normal development of the hypothalamic-pituitary-ovarian axis in the female rat (Barraclough, 1961). A similar 'critical period' for normal development of the hypothalamic-pituitary-testicular axis in the male rat has also been reported (Bercu, Jackson, Sawin, Safaii \& Reichlin, 1977). A single dose of antiserum to luteinizing hormone-releasing hormone (LH-RH) given to adult rats inhibited pituitary-gonadal function for no more than 7 days, whereas multiple doses of antiserum during the first 5 days after birth produced impairment of gonadal function during adult life, as manifested by infertility and reduced weight of testes and secondary sex organs (penis and seminal vesicles) in the presence of normal levels of serum gonadotrophins, testosterone and prolactin (Bercu et al., 1977). The purpose of this study is to report the impairment of LH-RH-induced gonadotrophin secretion in adult male rats that had been passively immunized against LH-RH in the neonatal period.

\section{Materials and Methods}

Sprague-Dawley rats (Charles River) were housed in a temperature-controlled room (25 \pm $1{ }^{\circ} \mathrm{C}$ ) with a daily lighting schedule of $14 \mathrm{~h}(06: 00-20: 00 \mathrm{~h})$ light and had free access to rat chow (Agway Company RMH 3000) and tap water. In Exps I, II and IV newborn rats were kept with their mothers until the 5th day of life. Then all the males were pooled and placed in groups of 8 with a suckling female. At 25 days of age the mothers were removed and the males were housed $4 /$ cage with treatment and control animals in equal numbers whenever possible.

† Present address: Building 10, Room 8D47, NIH, Bethesda, Maryland 20205, U.S.A. 


\section{LH-RH antiserum}

The antiserum was raised in rabbits (Jackson \& Reichlin, 1974) as described previously and its specificity was determined (Bercu et al., 1977). The antiserum showed no cross-reactivity with desamide-LH-RH, TRH, somatostatin, vasopressin, triiodothyronine, thyroxine, or angiotensin I or II. The antibody reacted with the C-terminal nonapeptide to pentapeptide fragments of LH-RH but not significantly with N-terminal fragments. A 1:280 000 dilution of antiserum bound $45 \%$ of labelled LH-RH under the conditions of our LH-RH radioimmunoassay.

\section{Radioimmunoassays}

LH and FSH were assayed by using the NIAMDD double-antibody radioimmunoassay kits with NIAMDD-rat-LH-RP1 and NIAMDD-rat-FSH-RP1 as the standards. The intra- and inter-assay coefficients of variation were 4.2 and $11 \%$, respectively for FSH and 7 and $17.8 \%$ respectively for LH. The sensitivities were $125 \mathrm{ng} \mathrm{FSH} / \mathrm{ml}$ and $25 \mathrm{ng} \mathrm{LH} / \mathrm{ml}$. The LH-RH radioimmunoassay was similar to that described by Nett, Akbar, Niswender, Hedlund \& White (1973). Briefly, LH-RH was labelled with ${ }^{125} \mathrm{I}$ with the use of chloramine $\mathrm{T}$ and purified on a Sephadex-G25 column. The sample, ${ }^{125} \mathrm{I}$-labelled LH-RH, and antiserum to LH-RH were incubated for $48 \mathrm{~h}$ and bound hormone was separated from free hormone by a double-antibody technique.

\section{LH-RH bioassay}

LH-RH activity was measured by a bioassay that was similar in principle to the technique described by Ramirez \& McCann (1966) and Seyler \& Reichlin (1974). Female SpragueDawley rats were ovariectomized and 1 month later were injected s.c. with $50 \mu \mathrm{g}$ oestradiol benzoate $+25 \mathrm{mg}$ progesterone in propylene glycol daily. The injections were given for 3 days before the assay and $50 \mu \mathrm{g}$ laevo-thyroxine were also injected s.c. on the 3rd day. The hypothalami to be studied were placed in $1 \mathrm{ml} 1 \mathrm{~N}$-acetic acid. The tissue was homogenized with a Polytron, and centrifuged at $2000 \mathrm{~g}$ for $30 \mathrm{~min}$. Then the supernatant was freeze-dried and stored at $-20^{\circ} \mathrm{C}$. Just before the assay the supernatant was redissolved in $1 \mathrm{ml}$ phosphatebuffered saline. The measure of LH-RH activity was the increment in serum LH concentratons $10 \mathrm{~min}$ after the administration of test substance to ether-anaesthetized rats. Text-figure 1 shows the standard dose-response curve for the LH-RH bioassay. Blood samples were removed from and injections were made into the external jugular veins.

\section{Experiment I}

Synthetic LH-RH (Bachem, California), $0.5 \mu \mathrm{g} / 100 \mathrm{~g}$ body weight $(0.5 \mu \mathrm{g} / 0.2 \mathrm{ml}$ normal saline $(9 \mathrm{~g} \mathrm{NaCl} / \mathrm{l})$, dose adjusted for group as a whole), was injected i.v. into 7 adult animals (100 days old) that had been given a single i.p. injection of $0.25 \mathrm{ml}$ antiserum to $\mathrm{LH}-\mathrm{RH}$ at 5 days of age. Six littermate controls had been given an equal volume of normal rabbit serum. Under pentobarbital anaesthesia ( $5 \mathrm{mg} / 100 \mathrm{~g}$ body weight, s.c.), blood was obtained from the external jugular vein, before and $20 \mathrm{~min}$ after LH-RH administration, for LH and FSH determinations. At 60 min the animals were decapitated and trunk blood was obtained. In this and the other experiments, blood was collected in glass tubes, centrifuged in the cold at $1000 \mathrm{~g}$ for $20 \mathrm{~min}$ and the serum was frozen immediately and stored at $-20^{\circ} \mathrm{C}$ until assayed. 


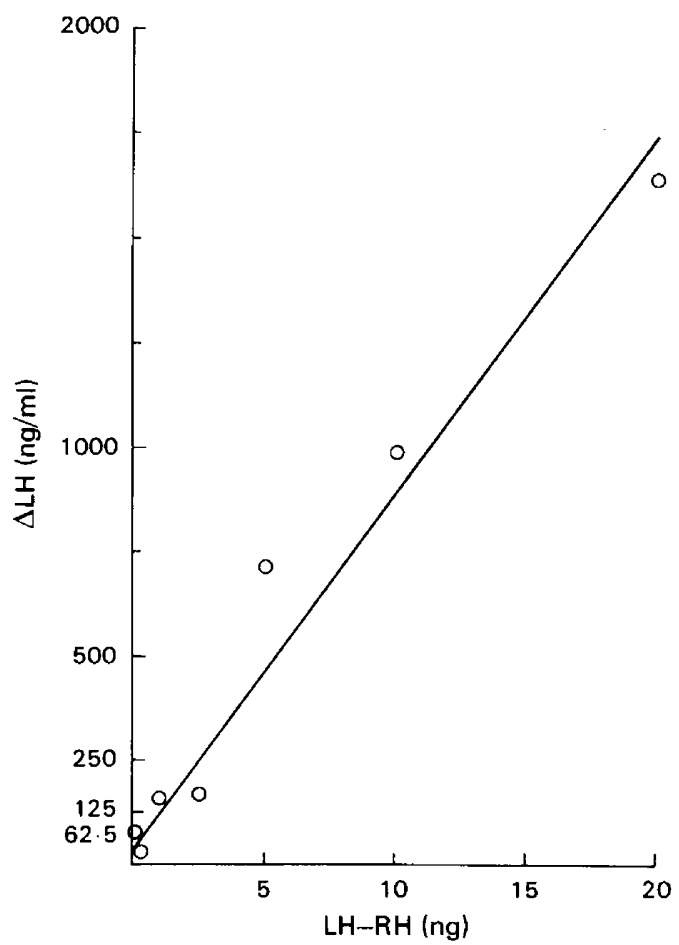

Text-fig. 1. Dose-response curve to synthetic LH-RH in ovariectomized rats pretreated with oestrogen and progesterone. The regression equation is $y=43.53 x+2.95, \mathrm{r}=0.98$. Each point represents $3-5$ animals.

\section{Experiment $I I$}

Males were treated with antiserum to LH-RH or normal rabbit serum on Day 5 after birth as in Exp. I. At 100 days of age the animals were killed and the anterior pituitaries were carefully dissected out, immediately frozen, weighed and stored at $-20^{\circ} \mathrm{C}$.

For assay of FSH and LH content the pituitaries were homogenized in $2 \mathrm{ml}$ distilled water with a Polytron (Brinkman). After rinsing with distilled water the homogenate was made up to $10 \mathrm{ml}$, centrifuged at $2000 \mathrm{~g}$ for $15 \mathrm{~min}$, and prepared as 3 dilutions. To measure the $\mathrm{LH}-\mathrm{RH}$ in the hypothalamus the brains were removed and the hypothalami, including the median eminences, were dissected. Tissue taken for the hypothalamic fragment was bounded anteriorly by the optic chiasma, posteriorly by the anterior margin of the mamillary sulcus, and dorsally by a plane connecting the anterior commissure and the anterior margin of the mamillary nucleus and placed into a glass vial containing $1 \mathrm{ml} 1 \mathrm{~N}$-acetic acid. These samples were frozen immediately and stored at $-20^{\circ} \mathrm{C}$. The tissues were thawed and then homogenized with a Polytron and centrifuged at $2000 \mathrm{~g}$ for $30 \mathrm{~min}$. The supernatant was freeze-dried and dissolved in assay buffer and measured at 3 dilutions in the $\mathrm{LH}-\mathrm{RH}$ radioimmunoassay.

\section{Experiment III}

Another group of untreated adult male rats aged 100 days was injected i.p. with $1 \mathrm{ml}$ antiserum to LH-RH $(N=6)$ or normal rabbit serum $(N=12)$. After 24 h the whole animals were perfused with saline to remove the blood and exogenous antiserum. They were decapitated and the brains were removed and the hypothalami, including median eminences, were dissected out and placed into glass vials containing $1 \mathrm{ml} 1 \mathrm{~N}$-acetic acid. Because of the possibility of 
contamination of hypothalami with the LH-RH antiserum, LH-RH content was measured by bioassay.

\section{Experiment IV}

Rats were treated neonatally (Day 5) with LH-RH antiserum $(\mathrm{N}=7)$ or normal rabbit serum $(N=7)$ as in Exp. I. At 70 days of age the abdomen was opened under ether anaesthesia. One vas deferens was isolated and incised; $2 \mu$ spermatic fluid were withdrawn for a sperm count. The animals were killed and testes and seminal vesicles were removed and weighed, the latter without extruding any seminal fluid.

\section{Statistical analysis}

Group comparisons were analysed with unpaired $t$ tests. All data are presented as mean \pm s.e.m.

\section{Results}

\section{Experiment I: $\mathrm{LH} / \mathrm{FSH}$ secretory response to $\mathrm{LH}-\mathrm{RH}$}

Basal serum LH and FSH were not significantly different in the experimental and control animals. However, the experimental rats showed a significantly greater response to LH-RH injections than did controls (Table 1).

Table 1. Serum LH and FSH concentrations $(\mathrm{ng} / \mathrm{ml})$ in 100 -day-old male rats treated at Day 5 of age with antiserum to LH-RH or normal rabbit serum and injected with $0.5 \mu \mathrm{g} \mathrm{LH-RH} / 100 \mathrm{~g}$ body weight

\begin{tabular}{ccccc}
\hline & & \multicolumn{3}{c}{ Time (min) } \\
\cline { 3 - 5 } \multicolumn{1}{c}{ Treatment } & Hormone & 0 & 20 & 60 \\
\hline Normal rabbit serum (controls) & LH & $65 \pm 9$ & $370 \pm 42$ & $580 \pm 121$ \\
Antiserum to LH-RH & FSH & $271 \pm 34$ & $392 \pm 40$ & $540 \pm 30$ \\
& LH & $83 \pm 6$ & $959 \pm 92^{* * *}$ & $1768 \pm 215^{* *}$ \\
& FSH & $315 \pm 38$ & $592 \pm 26^{*}$ & $860 \pm 45^{* * *}$ \\
\hline
\end{tabular}

Values are mean \pm s.e.m. for 6 (controls) or 7 (experimental) rats. Signficantly different from control value: * $P<0.05$; ${ }^{* *} P<0.01$; ${ }^{* * *} P<0.001$.

\section{Experiment II: pituitary content of $L H$ and FSH and hypothalamic content of $L H-R H$}

As shown in Table 2, the pituitary LH content in the experimental animals was significantly greater than that in control animals, but FSH content was unaffected. There were no differences between the groups for hypothalamic content of LH-RH.

Table 2. Pituitary content of FSH and LH and hypothalamic content of LH-RH in 100-day-old male rats treated at Day 5 of age with antiserum to LH-RH or normal rabbit serum

\begin{tabular}{|c|c|c|c|c|}
\hline \multirow[b]{2}{*}{ Treatment } & \multirow{2}{*}{$\begin{array}{l}\text { Pituitary } \\
\text { wt (mg) }\end{array}$} & \multicolumn{2}{|c|}{ Gonadotrophin content ( $\mu \mathrm{g} /$ pituitary) } & \multirow{2}{*}{$\begin{array}{c}\text { LH-RH } \\
\text { (ng/hypothalamus) }\end{array}$} \\
\hline & & LH & FSH & \\
\hline $\begin{array}{l}\text { Normal rabbit serum (controls) } \\
\text { Antiserum to LH-RH }\end{array}$ & $\begin{array}{l}9.2 \pm 0.7(6) \\
8.4 \pm 0.7(6)\end{array}$ & $\begin{array}{l}199 \pm 12(7) \\
314 \pm 3(6)^{*}\end{array}$ & $\begin{array}{l}142 \pm 9(7) \\
165 \pm 10(6)\end{array}$ & $\begin{array}{l}5.8 \pm 0.4(6) \\
4.5 \pm 0.5(6)\end{array}$ \\
\hline
\end{tabular}

Values are mean \pm s.e.m. for the number of animals in parentheses.

* Significantly different from control value, $P<0.01$. 


\section{Experiment III: LH-RH content by bioassay}

There was no difference in the content of LH-RH in the hypothalami of 6 experimental $(5 \cdot 3$ $\pm 1.8 \mathrm{ng})$ and 12 control $(4.9 \pm 1.2 \mathrm{ng})$ rats. These values are the same as those obtained by radioimmunoassay for the control adult male rats (see Table 2 ).

\section{Experiment IV: sperm count, and testicular and seminal vesicle weights}

The results are shown in Table 3 . Testicular and seminal vesicle weights differed significantly in the two groups but body weight and sperm count were similar.

Table 3. Sperm counts, body and organ weights in 70-day-old male rats treated at Day 5 of age with antiserum to LH-RH or normal rabbit serum

\begin{tabular}{lcccc}
\hline \multicolumn{1}{c}{ Treatment } & $\begin{array}{c}\text { Sperm count } \\
\times 10^{7} / \mathrm{ml}\end{array}$ & $\begin{array}{c}\text { Seminal vesicle } \\
\text { wt }(\mathrm{mg})\end{array}$ & $\begin{array}{c}\text { Testis wt } \\
(\mathrm{g})\end{array}$ & $\begin{array}{c}\text { Body wt } \\
(\mathrm{g})\end{array}$ \\
\hline Normal rabbit serum (controls) & $10 \cdot 8 \pm 1.0$ & $326 \pm 63$ & $3.34 \pm 0.60$ & $483 \pm 9$ \\
Antiserum to LH-RH & $9 \cdot 7 \pm 1.9$ & $130 \pm 30^{*}$ & $1.96 \pm 0 \cdot 10^{* * *}$ & $465 \pm 9$ \\
\hline
\end{tabular}

Values are mean \pm s.e.m. for $6-7$ animals.

Values significantly different from control; $* P<0.05 ;{ }^{* * *} P<0.001$.

\section{Discussion}

In this study the long-term effects of neonatal passive immunization with LH-RH antiserum was examined on the hypothalamic-pituitary-gonad axis of the adult male rat. Impairment of gonadal function occurred in adult animals although the blockade of LH-RH was transient (less than 7 days) (Bercu et al., 1977). Antiserum to LH-RH also transiently blocks ovulation in females (Koch, Chobsieng, Zor, Fridkin \& Lindner, 1973; Fraser \& Gunn, 1973; Makino, Takahashi, Yoshinaga \& Greep, 1973). Koch et al. (1973) demonstrated that the effect of LH-RH antiserum in adult female rats lasts for the duration of one oestrous cycle (4 days), although Kerdelhue, Catin, Kordon \& Justisz (1976) found long-term persistent oestrus after passive immunization at pro-oestrus.

The concentrations of serum LH and FSH rose significantly after LH-RH stimulation in adult male rats that had been passively immunized just after birth, but the pituitary content was increased only for LH. This discrepancy could have been due to a deficiency of endogenous LH-RH with its greater stimulatory effect on LH over FSH secretion (Schally, Kastin \& Arimura, 1971). Deficiency of LH-RH in our animals, however, might have been expected to cause a decrease in pituitary responsiveness to $\mathrm{LH}-\mathrm{RH}$, because $\mathrm{LH}-\mathrm{RH}$ is known to sensitize the pituitary to subsequent LH-RH injection (Fink, Chiapja \& Aiyer, 1976). In man, pituitary responses to LH-RH are markedly impaired in patients with long-term LH-RH deficiency and can be restored by repeated LH-RH injections (Schwarzstein, 1976; Mortimer, 1977). Nevertheless, Zeballos \& McCann (1977) have reported that adult female rats rendered hypogonadal by median eminence lesions have a transient period of hypersensitivity to LH-RH similar to the responses we report here, although subsequently the gonadotrophin responses became normal in their animals. It is possible that the increased response to LH-RH in our rats is due to permanent changes in the gonadotrophin receptors, perhaps related to sex-steroid deficiency at a critical developmental time induced by transient gonadotrophin deficiency. This hypothesis is consistent with the observations by Odell \& Swerdloff (1974) of a very sensitive negative feedback in young rats and the importance of sex steroids as regulators of pituitary gonadotroph sensitivity. 
In confirmation of our earlier findings (Bercu et al., 1977), testicular dysfunction, manifested by decreased testicular and seminal vesicular weights, was caused by neonatal treatment with LH-RH antiserum. Previously, we showed that the transient blockade of LH-RH in the neonatal rat did not prevent puberty and caused no permanent change in adult gonadotrophin or testosterone levels (Bercu et al., 1977). There were modest decreases in adult penile and seminal vesicular weights if the LH-RH antiserum was given early enough ( 1 day of age for penis weight and 5 days of age for seminal vesicle weight), suggesting that after a temporary neonatal decrease in effective LH-RH there was incomplete 'catch up' growth of these androgen-sensitive organs. The sperm concentration in the vas deferens was normal but the volume of ejaculate was possibly reduced because of the decreased seminal vesicular weight. Whether this can account for the reduced fertility of these animals (Bercu et al., 1977) is uncertain.

In adult animals treated with antiserum to LH-RH there was no change in bioassayable LH-RH in the hypothalamus $24 \mathrm{~h}$ after injection in spite of a known reduction in serum testosterone (Bercu et al., 1977). This suggests that the antiserum to LH-RH which flows to the portal from the systemic circulation via the inferior hypophysial artery in some way prevents LH-RH reaching its receptors in the adenohypophysis. Since the secretion rate of LH-RH has been estimated at around $0.1 \mathrm{mg} / \mathrm{min}$ (Ben-Jonathan, Mical \& Porter, 1974) and the portal plasma concentration of LH-RH is no more than $30 \mathrm{pg} / \mathrm{ml}$ (Eskay, Mical \& Porter, 1974), immunoneutralization of $\mathrm{LH}-\mathrm{RH}$ in the portal vasculature could explain the acute fall in testosterone that occurred. In-vitro studies with hypothalamic fragments (Rotsztein, Charli, Patton, Epelbaum \& Kordon, 1976) would be necessary to show whether there is an additional direct effect on LH-RH neurones.

These studies indicate that transient inhibition of LH-RH activity in neonatal life has long-term effects on both pituitary and testicular function.

This work was supported in part by U.S.P.H.S Grant Am-07039-02 and by Training Grant No. 5T01-HD 00033-18. We thank Dr S. Reichlin and Dr M. Cornblath for advice and editorial assistance; Ms J. Bollinger and $\mathrm{Mr}$ R. Haupt for technical assistance; Ms D. Jarvis for secretarial assistance; and Dr A. Parlow and the NIAMDD Rat Pituitary Program for the radioimmunoassay kits.

\section{References}

Barraclough, C.A. (1961) Production of anovulatory, sterile rats by single injections of testosterone propionate. Endocrinology 68, 62-67.

Ben-Jonathan, Mical, R.S. \& Porter, J.C. (1974) Transport of LRF from CSF. Endocrinology 95, 18-25.

Bercu, 8.B., Jackson, I.M.D., Sawin, C.T., Safaii, H. \& Reichlin, S. (1977) Permanent impairment of testicular development after transient immunological blockade of endogenous luteinizing hormone releasing hormone in the neonatal rat. Endocrinology 101, 1871-1879.

Eskay, R.L., Mical, R.S. \& Porter, J.C. (1974) LRH levels in hypophysial portal plasma (HPP). Fedn Proc. Fedn Am. Socs exp. Biol. 3, 211, Abstr.

Fink, G., Chiappa, S.A. \& Aiyer, M.S. (1976) Priming effect of luteinizing-hormone-releasing factor elicited by preoptic stimulation and by intravenous infusion and multiple injections of the synthetic decapeptide. J. Endocr. 69, 359-372.

Fraser, H. \& Gunn, A. (1973) Effects of antibodies to luteinizing hormone-releasing hormone in the male rabbit and on the rat oestrous cycle. Nature, Lond. 244, 160-161.
Jackson, I.M.D. \& Reichlin, S. (1974) Thyrotropin releasing hormone (TRH). Distribution in hypothalamic and extra hypothalamic brain tissues of mammalian and submammalian chordates. Endocrinology 95, 854-862.

Kerdelhue, B., Catin, S., Kordon, C. \& Jutisz, M. (1976) Delayed effects of in vivo LHRH immunoneutralization on gonadotropins and prolactin secretion in the female rat. Endocrinology 98, 1539-1549.

Koch, Y., Chobsieng, P., Zor, U., Fridkin, M. \& Lindner, H.R. (1973) Suppression of gonadotropin secretion and prevention of ovulation in the rat by antiserum to synthetic gonadotropin releasing hormone. Biochem. Biophys. Res. Commun. 55, 623-629.

Makino, T., Takahashi, M., Yoshinaga, K. \& Greep, R.O. (1973) Ovulation blockade in rats by rabbit anti-luteinizing hormone releasing factor in serum. Contraception 8, 133-145.

Mortimer, C.H. (1977) Clinical applications of the gonadotrophin releasing hormone. In The Hypothalamus and Pituitary (Clinics in Endocrinology and Metabolism No. 6), pp. 167-179. Ed. G. M. Besser. W. B. Saunders Company, Philadelphia. 
Nett, T.M., Akbar, A.M., Niswender, G.D., Hedlund, M.T. \& White, W.F. (1973) A radioimmunoassay for gonadotropin-releasing hormone (Gn-RH) in serum. J. clin. Endocr. Metab. 36, 880-885.

Odell, W.D. \& Swerdloff, R.S. (1974) The role of the gonads in sexual maturation. In The Control of the Onset of Puberty, pp. 313-341. Eds M. M. Grumbach, G. D. Grave \& F. E. Mayer. John Wiley and Sons, New York.

Ramirez, V.D. \& McCann, S.M. (1966) A highly sensitive test for LH-releasing activity: the ovariectomized, estrogen progesterone-blocked rat. Endocrinology 73, 193-198.

Rotsztein, W.H., Charli, J.L., Patton, E., Epelbaum, J. \& Kordon, C. (1976) In vitro release of luteinizing hormone-releasing hormone (LH-RH) from rat mediobasal hypothalamus: effects of potassium, calcium and dopamine. Endocrinology 99, 16631666.
Schally, A.V., Kastin, A.J. \& Arimura, A. (1971) Hypothalamic follicle-stimulating hormone (FSH) and luteinizing hormone ( $\mathrm{LH})$-regulating hormone: structure, physiology, and clinical studies. Fert. Steril. 22, 703-721.

Schwarzstein, L. (1976) Diagnostic and therapeutic use of LH-RH in the infertile man. In Current Topics in Molecular Endocrinology, Vol. 3. pp. 73-91. Eds F. Labrie, G. Meites \& G. Pelletier. Plenum Press, New York.

Seyler, L. E., Jr \& Reichlin, S. (1974) Episodic secretion of luteinizing hormone-releasing factor (LRF) in the human. J. clin. Endocr. Metab. 39, 471-478.

Zeballos, G. \& McCann, S.M. (1977) Increased responsiveness to LH-releasing hormone (LHRH) in rats with median eminence lesions. Proc. Soc. exp. Biol. Med. 154, 242-245.

Received 19 December 1979 